\title{
A Correlational Study of Digital Literacy Comprehension Toward Students' Writing Originality
}

\section{Nur Muthmainnah}

Institut Agama Islam Negeri (IAIN) Salatiga, Indonesia. Email: nur_muthmainnah@iainsalatiga.ac.id

\begin{tabular}{l} 
ARTICLE INFO \\
\hline Keywords: \\
Digital literacy; Correlation; \\
Originality of writing \\
How to cite: \\
Muthmainnah, N. (2019). A \\
Correlational Study of \\
Digital Literacy \\
Comprehension Toward \\
Students' Writing \\
Originality. Langkawi: \\
Journal of The Association for \\
Arabic and English, 5 (1), 45- \\
54 \\
DOI: \\
http://dx.doi.org/10.31332 \\
Llkw.v5i1.1151 \\
\hline
\end{tabular}

\begin{abstract}
This research was aimed to know how far the students' understanding of digital literacy, to know how high the students' writing originality, and to know the correlation between students' understanding of digital literacy and students' writing originality. Digital literacy is someone's capability to use the digital device, receive, communicate the process, evaluate, and share the information cognitively and technically. Originality is emphasized in writing because it is used as the measurement of the writers' idea and creativity in writing. This research used a correlational study to check the correlation between variable. The population of this research was the eighth-semester students of English Education Department Students of IAIN Salatiga. It used cluster random sampling to decide the sample of this research. Class A was used as the sample of the research that consisted of 32 students. The data that was collected was analyzed using SPSS 20. Based on the data analysis, it resulted that $r$ (count) $0.83>r$ (table) 0.349 . From the result, it can be concluded that there was a positive perfect correlation between digital literacy understandings with student's writing originality.
\end{abstract}

\section{Introduction}

Nowadays, internet existence is extremely helpful for human life. It facilitates our everyday needs. Everyone has taken advantage of the internet for their daily needs such as for communicating, finding and sharing information, enlarging knowledge, and promoting their product and business. Using internet as the mean of communication is quite cheaper than using telephone cable or cellular phone. The effectiveness and efficiency of using internet make most people use the internet as an important part of their daily life. In the other hand, the internet gives some bad impact to some people when it is used unwisely.

The Internet also gives some moderation in education. The teacher is able to use internet as the teaching media and as the source of learning. Internet also facilitates students to learn and get knowledge except for their teachers. Internet provides billions of information dealing with learning material.

The ease of getting any information sometimes makes students less creative. They tend to copy paste the material from the internet to fulfill their task. This case also happens to my students' case. When students were given a task to construct a text or paragraph, they did not write using their own words. Some students took text from the internet without paraphrasing and adding the reference. One of the problems why 
students tend to copy paste the task is that they do not know exactly that what he did was something violence in the academic world. The other problem is that students are less aware of their writing originality; they tend to think about how to fulfill the task as quick as possible. In the other hand, originality in an academic paper is very crucial because it is written based on theory or the result of a research that can be accounted for what was written in it and used a series of methodology (Arifin 2008). Originality is one of the components in writing which is measured (Haggarty, 2015) . Measuring the students' writing originality is important to know whether their writing is originality derived from their idea or stealing from other sources. The originality of writing deals with creativity. Students with high creativity in writing will have high originality too. On the contrary, students who have poor originality in writing, he also has low creativity in writing.

Originality also deals with plagiarism activity. Plagiarism is one of academic crime when someone quoted or took someone's idea without citing correctly. Plagiarism is constituting someone's words in any academic exercise intentionally or consciously (Ercegovac, 2014). Many plagiarism problems are faced in the academic world such as there are some graduating papers, theses, even dissertations were failed to be examined because of plagiarism action in composing them. As the academician, we should stop this action.

To avoid plagiarism, it needs awareness of using internet smartly. Every internet user should know and master digital literacy. Digital literacy itself was firstly introduced by Paul Gilster in 1997 as the ability to understand and use information in multiple formats from a wide variety of sources when it is presented via computer (Phuapan, Viriyavejakul, \& Pimdee, 2016). Seeing the skills described in digital literacy, there are still many internet users in Indonesia who have not already attained skills in digital literacy. It is proven with the increasing hoax information that is expanded and shared quickly from one to others through social media. It also happens to our students. Without evaluating the information, students directly copy and paste the material from the internet. To cope with all the problems in dealing with the internet, every internet user should master digital literacy well.

Murray (2016) conducted research entitled Digital Literacy for Language Learning and Teaching. This research was conducted to know how digital literacy was applied in language learning and teaching. After conducting research, it showed that digital literacy played an important role to improve language learning especially improving productive skill. While the research which would be conducted by the writer focused on the correlation between digital literacy understanding and writing skill especially its originality. A research entitled an Analysis of Digital Literacy Skills among Thai University Seniors which was conducted by Phuapan (2016). This research was conducted to know which skill of digital literacy which was adapted from Bloom Taxonomy Thai University seniors master digital literacy. After conducting a survey, it showed that Based on Bloom Taxonomy indicators, Judging was the most skill which was used by Thai University Students to use, communicate, operate, access, and share information digitally. While the research which would be conducted focused on students' digital literacy understanding that later on is correlated with their originality of writing. A study on the Effect of Digital Literacy on Information Use Behavior, a research which was held by Noh (2017). This study applied a survey to know the level 
of the effect of the digital literacy categories and sub-groups on information use behavior. The result of this study is that bit literacy influences information use behavior most, then followed by virtual community literacy and technical literacy. Then, the research which would be conducted, the writer would like to know the level of significance of the correlation between digital literacy understanding and originality of writing.

Seeing the crisis of originality in writing among students' paper, it interacts the writer to conduct a research whether there is a correlation between digital literacy understanding and students' writing originality. The objectives of this research are to know the correlation between digital literacy understanding and the originality of students' writing; how high students understanding of digital literacy; and how high the originality of students' writing.

\section{Literature review}

Digital literacy is someone's ability to engage with complicated information and up to dated technology rather than simply reading and writing information (Bawden, 2001). This ability will support someone to engage with his activities which deal with cultural and social things by using many kinds of media (Kwon \& Hyun, 2014). Digital literacy is defined as someone's skill to use technology to communicate, evaluate, share information cognitively and technically well (ALA, 2012). It also mentions five things that someone should own to be a digitally literate person. They are: owns many skills (technical and cognitive skills) including finding, comprehending, evaluating, creating, and communicating digital information using various formats; able to operate various technology to search information, draw conclusion, and create a judgement about the quality of the information; comprehend well about the relationship among life-long learning, technology development, processing information, and personal privacy (ALA, 2012). In addition, Visser (2013) stated that in the twenty-first century, digital literacy skills are the keystone to educational achievement, economic development, and workforce readiness. Buckingham (2015) tends to define digital literacy that it is not only about operating the computer well but also how to locate and select material, how to use browsers, hyperlink and search engine, evaluate and use the information.

Based on Noh (2017) there are three elements that base the digital literacy skills; technical literacy skill, bit skill, and virtual community skill. Each skill has its own indicators which should be owned. The indicators of technical literacy are able to operate hardware and tools, able to use windows, able to edit documents and use tools, able to use web browsers, and able to communicate. The indicators of bit literacy include the ability to search for information, ability to edit information, ability to process information, and ability to use information. The indicators of virtual community literacy are able to participate in the community, able to form self-identity, able to have a relationship, able to problem solve collectively, able to create cyberculture. According to Chase and Laufenberg (2011) digital literacy is called inherently squishy, a term which defines digital literacy as the ability from being technology fluent to the ability to apply information literacy skills (ability to locate, extract, organize, manage, present, evaluate information) in digital environments to broader, more complex conceptual frameworks that encompass a wide range of skills, understanding, practice, and norm. In addition, digital media literacy is related to the 
ability to use a computer, social media, and the internet and people with high levels of digital media literacy are more active in social affairs and better able to express their opinion (Hobbs, 2010).

From the concepts above, it can be drawn a conclusion that digital literacy is someone competency in operating digital tools to receive, communicate, process, evaluate, share information cognitively and technically. Then, the indicators to measure that someone is called has high digital literacy when someone has three mean criteria; (a) Skill to use technology / technical skill: someone is able to use or operate software or digital program (Ms. Office, computer software, search engine, communication platform, and so on) that is used to organize, evaluate, and communicate information; (b) Skill to demonstrate information/ bit skill: someone knows ethical concept sharing legal news/ information using information technology (c) Skill to create virtual communication: someone is able to communicate virtually.

An academic paper is written to share logical and systematic information to the reader. The most academic structure has typical structures which mainly consists of an abstract, introduction, and discussion that become "doors and windows" through which a reader is most likely access to the article (Kotze, 2007). In the other hand, writing an English scientific paper is not easy for second language students. One of the problems faced by Indonesian students is that they have difficulty in transferring their idea from the Indonesian language into English (Fauziati, 20017). In addition, most students feel terrified when they are challenged to write an academic article (Kotze, 2007). To cope with that problem, some students did dishonesty in writing their paper. They almost copy and paste their task from the internet because of their less understanding in reading the sources (Borg, 2000).

Originality is tightly connected with identity (Abasi, Akbari, \& Graves, 2006). Representation of author and his identity is a crucial thing in writing an academic paper when we quote his idea or when the state of something originating from a place or person is relevant to our opinion (Zergollern-Milletic \& Horvath, 2009). Originality in scientific writing means not only copying text but also creative, inventive, and novel, and contains new ideas or concept (Krapez, 2013). Writing original text will improve students' writing skill and knowledge (Prior, 2001). For undergraduate students, originality is in the reproductive skill where the information is presented based on the analysis (Pugh, 1994). The process to get writing originality can be reached by using the following process: re-thinking, re-constructing, and re-read the material and the following process is called as recasting process in writing (Larusson, 2010).

\section{Method}

This research applied a quantitative approach that used a correlational method. According to (Gall, 2003) correlational study is aimed to determine the correlation between variables using correlational statistics. This research was used to know the significance of the correlation between students' comprehension of digital literacy and the originality of their writing.

The population of this research was the eighth-semester students of English Education Department of IAIN Salatiga which consisted of 6 classes where there are 30-35 students in each class. This research used cluster random sampling to determine 
the sample. Class A was taken as the sample of the research which consisted of 32 students in the class.

The variable is a thing used as the object of research observed. Another statement from (Suryabrata, 1999) that variable is the factor that influences in the research case. There are two variables of research used in this research; Variable $X$ of this research was students' understanding of digital literacy, and variable $Y$ was the originality of students' writing.

To measure the two variables, it needs the indicators. Indicators are used as the guide to measure how far students understand digital literacy and how authentic students' writing. The indicator of digital literacy understanding is: (a) Skill to use technology: someone is able to use or operate software or digital program ( Ms. Office, computer software, search engine, communication platform, and so on) that is used to organize, evaluate, and communicate information; (b) Skill to use computer: someone is able to operate computer, tablet, printer, media player, and so on; (c) Skill to demonstrate information: someone knows the ethical concept sharing legal news/ information using information technology. While the indicator of the originality of scientific writing is: (a) the honesty of quoting someone's idea; and (b) writing the citation correctly. Besides that, to measure the students' originality, the writer also used Plagiarism $X$ application to check the similarity of students' writing.

To know the level of originality of students' writing, it applied plagiarism checking to the students' paper using plagiarism $X$ application. The result of plagiarism checking was used as the measurement of whether students' writing was original or not. The score of originality was taken from the total score of similarity the score of similarity resulted from the plagiarism checking. The higher similarity resulted will make the lower originality yielded. After getting the whole score, they were classified into 4 levels. Very high, high, average, and low.

The research instrument was an instrument that was used to collect the data. This research used a questionnaire and documentation as the instrument of this research. The questionnaire was constructed to know the students' understanding of digital literacy. It consisted of 50 statements that should be checked by students based on their condition by giving checking list whether they did or not, master or not based on the indicator of digital literacy skill. The documentation was the students' paper. The documentation was used to measure the students' writing originality. After collected, the documentation was checked using plagiarism $X$. then the result of plagiarism checking was used to determine the students' writing originality.

The following steps were used by the writer to analyze the data: (a) Counting the result of questionnaire; (b) Calculating the result of plagiarism checking, the higher result of plagiarism checking the lower score of students' writing originality and vice versa; (c) The data then presented and calculated using Pearson Product Moment to know the correlation between the variables, the writer used SPSS 20 application to get the result of this correlation; (d) after it resulted, the writer interprets the result of SPSS operation to know the correlation.

\section{Findings}

After conducting data collection, the data was analyzed using SPSS 20 program that applied the Pearson Product Moment to know the correlation between two variables. The result of the operation of SPSS 20 was presented below: 
Table 1. The Result of Product Moment Correlation using SPSS 20

\begin{tabular}{|c|c|c|c|}
\hline & & Digital Literacy Understanding & Originality of Writing \\
\hline Digital Literacy & $\begin{array}{l}\text { Pearson } \\
\text { Correlation }\end{array}$ & e & $.830^{* *}$ \\
\hline Understanding & Sig. (2-tailed) & & .000 \\
\hline & $\mathrm{N}$ & 32 & 32 \\
\hline Originality of & $\begin{array}{l}\text { Pearson } \\
\text { Correlation }\end{array}$ & $.830^{* *}$ & 1 \\
\hline Writing & Sig. (2-tailed) & .000 & \\
\hline **. Correlation is & $\begin{array}{l}\mathrm{N} \\
\text { nificant at the }\end{array}$ & vel (2-tailed). & 32 \\
\hline
\end{tabular}

Based on the analyses of SPSS 20 above, it showed that the score of significance coefficient of correlational test between digital literacy understanding and originality of writing was 0.000 . The coefficient score was lower than 0.005. it showed that there was significance between two variables. Two variables have a correlation when $\mathrm{r}$ count $>$ than r-table. The r-count of this operation was 0.83 . The r-table for 32 samples with the level of significance $5 \%$ is 0.349 . It can be concluded that there was a correlation between variable $\mathrm{X}$ (digital literacy understanding) and variable $\mathrm{Y}$ (Originality of writing).

To measure the level of correlation, the writer used the following table:

Table 2. Level of Correlation

\begin{tabular}{cl}
\hline r-count Score & \multicolumn{1}{c}{ Level of Correlation } \\
\hline $0.00-0.199$ & Very Low correlation \\
$0.20-0.399$ & Low correlation \\
$0.40-0.599$ & Moderate correlation \\
$0.60-0.799$ & Strong correlation \\
$0.80-1.00$ & Very Strong correlation \\
\hline \multicolumn{2}{c}{ Source: (Sugiyono, 2013) }
\end{tabular}

The correlation score or r-count form the SPSS 20 operation between digital literacy understanding and originality of writing was 0.83 . According to the table above, 0.83 is in a very strong correlation level. So, it can be concluded that there was a perfect correlation between digital literacy understanding and originality of writing.

If the $r$-count approaches 1 , it means that there is a positive correlation between two variables; if the $r$-count approaches -1 , it means that there is a negative correlation between two variables (Mairing, 2017). The r-count of this test was 0.83 or approaching 1. It means that there was a positive correlation between the two variables.

From the analysis above, it can be concluded that there was a perfect positive correlation between variable $\mathrm{X}$ (digital literacy understanding) and variable $\mathrm{Y}$ (originality of writing).

\section{Hypothesis testing}

Statistic hypothesis is a temporal presumption of population parameter which will be tested through data collection (Mairing, 2017). The writer had presented the result of correlation testing between variable $X$ (digital literacy understanding) and variable $\mathrm{Y}$ (originality of writing) before. It resulted that, there was a correlation between two variables. 
The hypothesis can be formulated as follows:

1. $\mathrm{H}_{0}$ (null hypothesis): there is no correlation between digital literacy understanding and originality of writing or r-count $<$ r-table.

2. $\mathrm{H}_{\mathrm{a}}$ (alternative hypothesis): there is a correlation between digital literacy understanding and writing originality or r-count $>$ r-table.

Based on the analyses conducted before, it showed that $r$-count 0.83 is higher than $>$ r-table 0.349. It can be concluded that $\mathrm{Ha}$ is accepted and $\mathrm{Ho}$ is rejected.

\section{Discussion}

\subsection{The level of Students' Digital Literacy Understanding}

After calculating the result of the questionnaire of students' digital literacy understanding, it showed that most students have a good understanding of digital literacy. It was proven with the result of the percentage that there were $34 \%$ or 11 students who have a very good understanding of digital literacy, and $44 \%$ or 11 students have a good understanding of digital literacy. The mid-point of this questionnaire is 74 or at a good level. It can be concluded that average students of English Education Department have a good understanding of digital literacy.

The level of understanding owned by the students is very normal because almost students were born on $2000^{\text {th }}$ it means that they are netizen generation or digital native where this generation is accustomed to operation and using digital tool for their life since their childhood. Digital native can be defined as a generation where they were born in the digital era. They could think, and find information greater, distinctively, and basically, than people older than them, it was the effect of the environment and higher digital interaction (Prensky, 2001). According to a research conducted by Noh (2017) it also shows that adult learners have a higher understanding of digital literacy which is varied in skills based on their learning passion and major.

\subsection{The level of originality of writing}

Based on the plagiarism checking and scoring analysis, it yielded that there were $44 \%$ or 14 students who had a very high level of originality for their writing; $19 \%$ or 6 students of them were in high level of originality of their writing; $28 \%$ or 9 students were on average level, and the remaining or $9 \%$ or 3 students were classified into the low level of originality of their writing. The average score of the originality of students' writing was 70 or at a high level. Based on the presentation of the data above, it can be concluded that almost students of English Education Department have a high level of originality in their writing. Students have been already aware of how important originality in writing.

The originality of writing can be seen from students' construction which can be read smoothly and connected from one sentence to others. It is also proven with what Zergollern et.al (2009) found in their research that the less original an idea and its framing is, the more likely that its reception will be followed easily. In addition, writing an English paper has become their usual task for some subjects they took. Some lectures emphasized originality for their paper. In addition, according to Janet (Salmons, 2018) research, teaching the proper use of source by defining plagiarism and educating learners in methods for citation is one of the suggestions to avoid plagiarism practice at the university. 


\subsection{The Correlation of Digital Literacy Understanding and Originality of Writing}

According to the result of data analysis, it showed that there was a positive correlation between digital literacy understanding and originality in writing. The correlation between two variables was a very strong correlation with the score of r-test is 0.83 which is higher than r-table 0.349. it proved that the higher understanding of digital literacy will affect the high score of the originality of students' writing. However, it found that there was students' understanding of digital literacy was at a high level (70), his originality of writing was at an average level (33). After conducting a mini interview with the student who got this score, it was found that the lack of selfconfidence to write using his own idea and construction.

The phenomenon above is proven with what (Small, Arnon, Stripling, \& Berger, 2012) stated that the reason of young people do not apply their digital literacy understanding is that they lack someone to motivate them. Thus, a student with high digital literacy understanding but having low self-confidence which was found in this research should be motivated to avoid the plagiarism practice. In addition, digital literacy is needed and employed frequently where learning, media, and technology are emphasized every day which are largely contributed by young people (Meyers, Erickson, \& Small, 2013). So, to build a learning atmosphere with higher digital literacy where there is an engagement of practices including digital tools and media, it needs to create more activities which involve those things more (Gee \& Hayes, 2011).

\section{Conclusion}

Based on the data analysis, the data met the requirement and the hypothesis was accepted. The research hypothesis is that there is a correlation between digital literacy understanding and the originality of writing in the students of English Education Department of IAIN Salatiga. after the discussion conducted, it can be drawn some conclusion that; First, The average of eighth semester students of English Education Department has a good understanding of digital literacy; Second: The average score of their questionnaire of digital literacy understanding was 74.4; Second, The average of eighth semester students of English Education Department have high originality of their writing. It was proven with their originality score. The average score of originality was 70 that can be classified into the high level; Third, There was a positive and very strong correlation between digital literacy understanding and originality of writing in the eighth-semester students of English Education Department with the result of the correlational test that r-count $0.83>$ r-table 0.349 .

From the result of research above, the writer could share some suggestion that: (a) Lecturers should motivate students to write and share his won idea because it is important to avoid plagiarism activity in writing; (b) Lecturers should strengthen the writing material in paraphrasing and writing quotation in their writing class; (c) Students should be given such training or seminar toward the important of originality of writing and how to conduct it in their scientific writing; (d) Conducting a research to dig up the role of motivation in the originality of writing is needed to prove the unique result of this research. 


\section{References}

Abasi, R. A., Akbari, R., \& Graves, B. (2006). Discourse Appropriation, Construction of Identity, and the Complex Issue of Plagiarism: ESL Students Writing in Graduate School. Journal of Second Language Writing, 102-117.

ALA, A. L. (2012). Digital Literacy, Libraries, and Public Policy: Report of the American Library Association Digital Literacy Task Force. Chicago: ALA. Retrieved April 9, 2018, from ALA Connect: http://connect.ala.org/node/181197

Bawden, D. (2001). Information and Digital Literacies: A Review of Concepts. Journal of Documentation, 218-259.

Borg, E. (2000). Citation Practices in Academic Writing. UK: Center for Applied Language Studies.

Buckingham, D. (2015). Defining Digital Literacy. Nordic Journal of Digital Literacy, 2134.

Chase, Z., \& D, L. (2011). Embracing the Squishiness of Digital Literacy. Journal of Adolescent $\mathcal{E}$ Adult Literacy, 535-537.

Ercegovac, Z. (2014). Plagiarism of Print and Electronic Resources. College E Research Libraries, 2.

Fauziati, E. (20017). Teaching English as a Foreign Language (TEFL II): Principle and Practice. Surakarta: Era Pustaka.

Gall, M. D. (2003). Educational Research: An Introduction. New York: Pearson Education, Inc.

Gee, J. P., \& Hayes, R. E. (2011). Language Learning in the Digital Age. New York: Routledge.

Haggarty, S. (2015). Originality in Creative Writing. Retrieved April 9, 2018, from Stephanie H: stephaniehaggarty.com

Hobbs, R. (2010). Digital and Media Literacy: A Plan of Action. Washington DC: Aspen Institute.

Kotze, T. (2007). Guidelines on Writing a First Quantitative Academic Article. Pretoria, South Africa.

Krapez, K. (2013). The (un) Originality of Scientific Papers- An Analysis of Professional Quality Standard. Management, Knowledge, and Learning International Conference. Zadar: Make Learn.

Kwon, S., \& Hyun, S. (2014). A Study of the Factors Influencing the Digital Literacy Capabilities of Middle-aged People in Online Learning. Korean Journal of the Learning Sciences, 120-140.

Larusson, B. W. (2010). Detecting The Point of Originality in Student Writing. Technical Report, 1-5.

Mairing, J. P. (2017). Statistika Pendidikan. Jogjakarta: Andi.

Meyers, E. M., Erickson, I., \& Small, R. V. (2013). Digital Literacy and Informal Learning Environments: An Introduction. Learning, Media, and Technology, 355367.

Murray, F. F. (2016). Digital Literacies for Language Learning and Teaching: Developing a National Framework. 2nd International Conference on Higher Education Advances, Head' 16. Valencia: Universitat Politecnica de Valencia.

Noh, Y. (2017). A Study on the Effect of Digital Literacy on Information Use Behavior. JoLis (Journal of Librarianship and Information Science, 26-56. 
Phuapan, P., Viriyavejakul, C., \& Pimdee, P. (2016). An Analysis of Digital Literacy Skills among Thai University Seniors. I-jet, 24-31.

Prensky, M. (2001). Digital Natives, Digital Immigrant. On the Horizon, 1.

Prior, P. (2001). Voices in Text, Mind, and Society: Sociohistoric Accounts of Discourse Acquisition and Use. Journal of Second Language Writing, 55-81.

Pugh, E. P. (1994). How to get a Ph.D. USA: Open University Press.

Salmons, J. (2018). Honesty and Originality in Academic Writing. New York: SAGE Publishing.

Small, R. V., Arnon, M., Stripling, K., \& Berger, P. (2012). Teaching for Inquiry: Engaging the Learner Within. New York: Neal-Schuman Publisher.

Sugiyono. (2013). Metodologi Penelitian Kuantitatif, Kualitatif, dan $R \mathcal{E}$ D. Bandung: Alfabeta.

Suryabrata, S. (1999). Metode Penelitian. Jakarta: Raja Grafindo Persada.

Visser, M. (2013). Digital Literacy and Public Policy through the Library Lens. Maine Policy Review, 104-113.

Zergollern-Milletic, L., \& Horvath, J. (2009). Coherence and Originality in University Students' Writing. Empirical Studies in English Applied Linguistics, 135-151. 